UDC $616.23 / 25-000.34+616-089.843$

Nasadyuk C. M. ${ }^{1}$, Makhinya A. V. ${ }^{1,2}$, Shabliy V. A. ${ }^{2}$, Vyalykh Z. E. ${ }^{3}$ Zadorozhna V. I. ${ }^{3}$, Martynenko S. I. ${ }^{2}$

${ }^{1}$ Association of Cryobanks of Umbilical Cord Blood, Other Human Cells and Tissues, Kyiv, Ukraine

${ }^{2}$ Institute of Cell Therapy, Kyiv, Ukraine

${ }^{3}$ L. V. Gromashevsky State Institute of Epidemiology and Infectious Diseases of NAMS of Ukraine, Kyiv, Ukraine

e-mail: nasadyukch@gmail.com

\title{
LEGISLATIVE REGULATION OF THE BANKING OF UMBILICAL CORD BLOOD STEM CELLS, OTHER HUMAN CELLS AND TISSUES AND CLINICAL TRIALS WITH THEIR USE IN THE DIFFERENT COUNTRIES OF THE WORLD
}

\section{ABSTRACT}

The article highlights the experience and peculiarities of legislative regulation of umbilical cord blood and tissue banking in the different countries of the world as well as clinical trials with their application. The approaches to licensing and legislative regulation of the business activities of the cord blood banks in Ukraine are also described.

KEYWORDS: stem cells, umbilical cord blood, bank of umbilical cord blood, legislative regulation.

Recently methods of cell therapy and tissue transplants have been increasingly used in the treatment of malignant, degenerative, genetically mediated and other diseases worldwide [15, 16, 18, 19, 24]. As of 2015 , about 5,000 clinical trials on the evaluation of the effectiveness of stem cells in the treatment of different diseases are registered in the National Institute of Health (USA) [24]. According to the data of the Association of Cryobanks more than 34 million patients worldwide have indications to cell therapy [17]. In the USA only during recent 30 years more than 1 million patients were treated with the stem cells [17].

Among the sources of hematopoietic and mesenchymal stem cells an important place belongs to the umbilical cord blood that in 2006 was acknowledged by the European Group for Blood and Marrow Transplantation to be equivalent to the bone marrow [16, 43]. From 1988 more than 35,000 umbilical cord blood stem cell transplants were performed worldwide in children and adults [15] and cord blood banks became an inherent constituent of the system of health institutions both in developed and developing countries of the world [12,16,27]. As of 2013, the world registry of public cord blood banks contained more than 700,000 umbilical cord blood samples, HLA typed and ready for transplants [17]. It is known that much more umbilical cord blood samples are stored in the family cord blood banks [17]. It should be noted that if in the beginning of the 1990s, related cord blood transplants were dominating, beginning from 2000 , annually the number of unrelated transplants is increasing, that as of 2014 made about $90 \%$ from the total number of transplants performed from the moment of the first cord blood application in 1988 [15]. From 1988 to $2014,53 \%$ of cord blood transplants were performed in children and $43 \%$ operations - in adults. However, from 2008 number of umbilical cord blood transplants in adults annually over exceeds their quantity in children $[15,16]$. Also researchers and clinicians of the field express increasing interest to the mesenchymal stem cells of the placenta, umbilical cord, adipose tissue, teeth pulp, menstrual blood [12, 14, 24, 26]. The approaches to the treatment of musculoskeletal system injuries with the use of tenocytes cultures are being developed [14]. In particular, Ukrainian scientists from the Institute of Cell Therapy and Romodanov Institute of Neurosurgery of AMSU developed the technology of the treatment of herniated discs using cultivated autologous chondrocytes [17].

Because of the mentioned above tendencies of the world medicine, collection and processing of cellular material for the clinical purposes is considered to be as a unique method of the manufacturing of biologics, that implicate strict following of the determined rules for the provision of the high quality of the drug and avoiding contamination with microorganisms or cells of the other patient/donor. Manufacturing of cell drugs, processing, testing and cryostorage of tissues are strictly regulated by numerous international documents and should match the demands of the standards of Current Good Tissue Practice (cGTP) and Good Manufacturing Practice (GMP) [1, 2]. 


\section{LEGISLATIVE REGULATION OF THE BANKING OF UMBILICAL CORD BLOOD STEM CELLS, OTHER HUMAN CELLS AND TISSUES IN THE EUROPEAN UNION AND UNITED STATES OF AMERICA}

As mentioned above, banking of umbilical cord blood stem cells, other human cells and tissues is regarded as manufacturing of cell transplants, which:

- $\quad$ should be sterile;

- $\quad$ regarding umbilical cord blood sample, it should contain sufficient for hematopoiesis reconstitution number of viable cells, capable to engraftment and further functioning;

- $\quad$ to be free of the dangerous cryopreservatives [17].

From 1999 collection, testing and cryopreservation of the hematopoietic stem cells is coordinated by the Joint Accreditation Committee (JACIE)-ISCT (International Society for Cell Therapy) \& EBMT (European Group for Blood and Marrow Transplantation). European Directive on Transplantation of Cells and Tissues regulates application of hematopoietic stem cells both derived from the bone marrow and peripheral and umbilical cord blood. At that, activities of cryobanks and cell therapy clinics are regulated by the relevant national committees (table 1) [17, 25]. In 2008 in all state-members of the European Union legislation of the European Union on medical products for the novel therapy was adopted (advanced therapy medicinal products (ATMP) [14]

As indicated in the The Rules Governing Medicinal Products in the European Union of the EU Guidelines to Good Manufacturing Practice (Medicinal Products for Human and Veterinary Use) the process of transportation of the material from and to biobank is one of the most potent factors of contamination [3]. Because of this in the developed world a tendency to concentration of all manufacturing and laboratory processes, related to processing and testing of biomaterial on one base is noted. It is even recommended that the laboratory performing procession of the biomaterial is as close as possible to the clinic, where the cell preparation will be used [4]. In case of impossibility of the testing of biomaterial on the base of the biobank, international documents, regulating banking and application of cord blood stem cells and other human cells and tissues predefined demands to third parties, who in accordance to signed contract may provide diagnostic services to the biobank.

Thus, laboratory tests of the biomaterial should be performed only by the laboratory, accredited or licensed in EU according to actual legislation and licensing terms of FACT/NETCORD, FACT-JACIE International Standards. Test-systems and diagnostic kits, used for the testing, should be approved by the relevant regulating organs $[5,6]$. The personnel, performing laboratory testing of the umbilical cord or peripheral blood is demanded to have experience of work with the hematopoietic stem cells [7].

In 2007, Switzerland has modified Federal Act on the Transplantation of Organs, Tissues and Cells of 8 October 2004, RS 810.21. Thus, in Switzerland the collection of biological material and realization of all cell drugs should be performed in accordance with the standards of the Current Good Clinical Practice (cGCP guidelines for their procurement and collection), and manufacturing of cell and tissue preparations due to standards of Current Good Manufacturing Procedures (cGMP). These terms define strict criteria on all processes of manufacturing of cell drugs, demand the availability of clean rooms for their storage [14].

In Great Britain the laboratories, working with human cells and tissues should comply the terms of the state licensing authority - Human Tissue Authority (HTA), that are based on EU Directive 2004/23/EC. HTA licensing refers to all medical institutions of Great Britain, which isolate, store, test, process, use or distribute any human cells that will be used for patients treatment. Only HTA-accredited tissue banks may provide cells and tissues for therapies in medical institutions of the National Health Service (NHS). Also in Great Britain the laboratories engaged in testing of the biomaterial, i.e. or the banks of the human cells and tissues should be accredited by Clinical Pathology Accreditation - CPA
Table 1. Regulation of the activities of the banks of umbilical cord blood, other human cells and tissues in different countries of the world [25].

AUTHORITY, REGULATING THE ACTIVITIES OF THE BANKS COUNTRY OF THE UMBILICAL CORD BLOOD, OTHER HUMAN CELLS AND TISSUES

\begin{tabular}{|c|c|}
\hline Austria & $\begin{array}{l}\text { Bindesministerium fur Gesundheit, Familie, } \\
\text { und Jugend }\end{array}$ \\
\hline Belgium & $\begin{array}{c}\text { Agence Fédérale du Médicament et des Produits } \\
\text { de Santé (AFMPS-FAGG) }\end{array}$ \\
\hline Bulgaria & Executive agency for Transplantation \\
\hline Hungary & National Public Health and Medical Officers Service \\
\hline Germany & Bundesministerium fur Gesundheit \\
\hline Greece & Hellenic Transplant Organization (EOM) \\
\hline Denmark & Laegemiddelstyrelsen (Danish Medicines Agency) \\
\hline Ireland & Irish Medicines Board \\
\hline Spain & Organización Nacional de Trasplantes (ONT) \\
\hline Italy & Centro Nazionale Trapianti \\
\hline Cyprus & Ministry of Health of Cyprus \\
\hline Latvia & Latvian State Agency of Medicines \\
\hline Lithuania & Nacionalinis Transplantacijos Biuras \\
\hline Luxemburg & Ministere de la Sant \\
\hline Macedonia & Ministry of Health of the Republic of Macedonia \\
\hline Malta & Ministry for Health, Elederly and Community Care \\
\hline Netherlands & Ministerie van Volksgezondheid \\
\hline $\begin{array}{l}\text { United Kingdom } \\
\text { of Great Britain } \\
\text { and Northern } \\
\text { Ireland }\end{array}$ & Human Tissue Authority \\
\hline Portugal & $\begin{array}{c}\text { Autoridade para os Servicos de Sangue } \\
\text { e da Transplantacao }\end{array}$ \\
\hline Romania & Agentia Nationala de Transplant \\
\hline Slovak republic & Ministerstvo zdravotnictva Slovenskej republiky \\
\hline Slovenia & Slovenija transplant \\
\hline USA & Food and Drug Administration (FDA), ICCBBA \\
\hline Finland & Laakelaitos Lakemedelsverket \\
\hline France & Agence de la Biomédecine \\
\hline Croatia & $\begin{array}{c}\text { Ministrastvo Zdravstva i Socijalne Skrbi Republike } \\
\text { Hrvatske }\end{array}$ \\
\hline Czech Republic & Státní ústav pro kontrolu léčiv \\
\hline Sweden & $\begin{array}{c}\text { Socialstyrelsen (National Board of Health and } \\
\text { Welfare) }\end{array}$ \\
\hline Estonia & Ravimiamet (Estonian State Agency of Medicines) \\
\hline
\end{tabular}

CPA standards were adopted yet in 1993 and are constantly reviewed due to the demands of modern times [13].

American Association of Blood Banks (AABB) also approved standards on the activities of the institutions, engaged in processing, testing, cryostorage of peripheral and umbilical cord blood. Standards comply with all aspects of the activities of biobank, including screening and testing, processing, storage and all treatment results. All aspects of process- 
ing operations are covered by strict standards, demanding the compliance of all quality system [11].

Food and Drug Administration (FDA) in the USA considers cord blood stem cell as a biologic but not a blood preparation. Thus, processing of the umbilical cord blood is regulated not by the laws on donorship of blood and its components but rather as a pharmaceutical industry, associated with the drugs manufacturing $[8,9]$. Thus, demands to the material supply for the processes of manufacturing and quality control are significantly stricter. FDA rules implicate inspection of the biological safety of the umbilical cord blood. The list of FDA demands to the processes of processing, testing and cryostorage of cell products are almost identical to AABB and FACT standards. Laboratories, working with Human Cells, Tissues, and Cellular and Tissue-Based Products (HCT/Ps) should comply with modern FDA Standards of Good Tissue Practices.

Recently cord blood banking is actively developing in the countries of Arabic world, and although obligatory international laws, regulating national cord blood banks activities were not yet adopted there, compliance with the demands of the Foundation for the Accreditation of Cellular Therapy (FACT) is essential that the hematopoietic stem cell sample from the public banks may be included into the international registry [27]. Nowadays only 2 public cord blood banks in arabic world comply with international standards - these are the banks in the cities of Riyadh and Dubai [27]. At the same time the governments of the different countries may adopt alternative or additional laws, regulating cord blood banks activities.

Jordania was the first country in the Arabic world to adopt law, regulating research and application of the stem cells [27]. In Saudi Arabia the bioethics committee, founded in 2002, allows to conduct research on stem cells, including cord blood stem cells. The policy on control of the biobanks activities in Saudi Arabia is based on Fetves (Islamic law conclusions) of 2003, issued by the League of the Muslim World. Saudi Arabia allows the use of placenta or umbilical cord derived stem cells with the scientific or clinical purpose. The Ministry of Health of Saudi Arabia created the national committee, supervising the activities of cord blood banks, licensing procedures, adoption of laws [27].

Ministry of Health and Population of Egypt keeps broad strategy on the control of the cord blood banks activities, based on the ethical guidance of the USA and Europe. In 2007, Egypt approved the National Blood Policy, regulating procedures of collection and testing of the umbilical cord blood. The cord blood bank in Egypt in order to begin business activities should first obtain the permission of the al-Azhar university in Cairo [27].

Due to high medical and biological value of the umbilical cord blood, actually many countries of the world adopted laws, obligating the physicians to inform future parents about the possibilities of cord blood storage or donating it to the public banks. Thus, in 2005 the Institute of Medicine (IOM) in USA issued so called broad report on cord blood banking, containing accurate recommendations for the medical personnel on providing all expectant parents objective information on possibilities of cord blood storage before labor [42]. Department of Health and Human Resources in USA in its turn founded the National Cord Blood Inventory (NCBI) program, supporting banking of umbilical cord blood stem cells for the treatment of patients and scientific research. These cord blood samples are available for physicians and patients for unrelated stem cells transplants within C.W. Bill Young Cell Transplantation Program [17, 42].

Today 28 US states legalized educational programs on cord blood that cover $78 \%$ of all deliveries. Most of US states follow IOM recommendations, some states are on different stages of the development of this kind legislative procedures on the necessity of informing expectant parents on the opportunities of cord blood storage [17, 42].

The states which on the legislative level regulate educational initiatives on cord blood storage are Arizona, Arkansas, California, Colorado, Connecticut, Florida, Georgia, Illinois, Kansas, Louisiana, Maryland, Massachusetts, Michigan, Mississippi, Missouri, New Jersey, New Mexico,
Northern Carolina, Northern Dakota, Ohio, Oklahoma, Pennsylvania, Rhode Island, Tennessee, Texas, Virginia, Washington, Wisconsin. Among them in 13 states (Arizona, Connecticut, Georgia, Louisiana, Massachusetts, New Jersey, New Mexico, Oklahoma, Pennsylvania, Rhode Island, Texas, Virginia, Wisconsin) medical legislation obliges the personnel of the maternity clinics to inform expectant parents on the value and opportunities for donating or personal storage of the umbilical cord blood $[17,42]$. Also in USA in 2009, annex to the tax law was adopted due to which expenses of parents on personal cord blood storage are excluded from annual taxes [17].

Cryopreservation of the umbilical cord tissue and mesenchymal stem cells derived from it is a relatively new service in the field of biobanking. Since actually there are no laws in EU regulating this kind of services, collection, processing, testing and cryostorage of the umbilical cord is regulated by the same directives as the activity of the cord blood bank - NetCord-FACT International Standards, FACT-JACIE International Standards for Cellular Therapy Product Collection, Processing, and Administration and Directive 2004/23/EC of the European Parliament and of the Council of 31 March 2004 on Setting Standards of Quality and Safety for the Donation, Procurement, Testing, Processing, Preservation, Storage and Distribution of Human Tissues and Cells $[1,6,7]$. Also collection, processing and cryopreservation of the adult stem cells independently from the origin should be performed due to GMP standards [14, 26]. For example, in Switzerland manufacturing of cell drugs may be performed only in licensed laboratories due to GMP demands, which are reviewed by the Swiss Pharmacopeia [14]. cGMP contains special protocols on infrastructure, equipment and personnel and CGCP regulates clinical aspects of application of cell drugs.

The American Association of Blood Banks (AABB) approved accreditation standards on banking of somatic cells, which cover also isolation of cells from the umbilical cord tissue [12]. Cryopreservation of tissues in USA also is regulated by the American Association of Tissue Banks (AATB), issuing relevant accreditation license [12].

\section{LEGISLATIVE REGULATION OF CLINICAL TRIALS USING CELL DRUGS AND HUMAN TISSUES}

In EU countries clinical trials with the use of cell and tissue products are regulated by relevant documents:

- WHO: Operational Guidelines for Ethics Committees That Review Biomedical Research World Health Organization Geneva 2000 [28];

- UNESCO: International Declaration on Human Genetic Data: UNESCO, 1997 [29];

- EUROPEAN COUNCIL: Additional protocol to the convention on human rights and biomedicine concerning biomedical research; Convention for the protection of Human Rights and Dignity of the Human Being with Regard to the Application of Biology and Medicine: Convention on Human Rights and Biomedicine; Additional Protocol to the Convention on Human Rights and Biomedicine, concerning Genetic Testing for Health Purposes [30-33];

- EUROPEAN UNION (Directive 2001/20/EC of the European Parliament and of the Council of 4 April 2001 on the approximation of the laws, regulations and administrative provisions of the Member States relating to the implementation of good clinical practice in the conduct of clinical trials on medicinal products for human use, Directive 95/46/EC of the European Parliament and of the Council of 24 October 1995 on the protection of individuals with regard to the processing of personal data and on the free movement of such data, EU Directive 2004/23/EC: towards standards of quality and safety for human tissues and cells in Europe; Directive 2004/23/EC of the European Parliament and of the Council of 31 March 2004 on setting standards of quality and safety for the donation, procurement, testing, processing, preservation, storage and distribution of human tissues and cells.) [34-37]. 
According to mentioned above documents, in European Union the authority that issues permission for clinical trials of cell and tissue transplants is the Central Commission on Bioethics, which is an independent organ. Central Commission on Bioethics also performs control of trials, accepts current and final reports.

Formation of commission on bioethics and its activity is described in details in WHO Guidance on Bioethical Committee, which reviews biomedical trials and is many times mentioned in European directives and other documents.

In Europe a drug after clinical trials is approved to clinical application by the European Agency for the Evaluation of Medicinal Products.

Also in European legislation significant attention is paid to the conditions of conduction of genetic tests, associated with DNA/RNA analysis in the context of hereditary information, chromosomal analysis etc. This information is supposed to be especially sensitive and should be given a special status what is stated in numerous protocols, regulating conducting of such trials, processing and preservation of their results.

In European legislative base, regulating conducting of clinical trials, especially significant attention is paid to the aspects of obtaining of informed consent from the participant of the trial as well as the procedure of obtaining of informed consent from disabled persons, who are provided a special status.

Legislation on studies of cells and tissues does not amplify to the use of embryonic, reproductive and genetically modified cells as well as xenotransplants (from animals). Legislative acts for the regulation of the application of embryonic and genetically modified cells and xenotransplants is on the stage of developing. Institutions, performing transplants, should have relevant accreditation and be inspected every 2 years. JACIE is the international accrediting committee of transplant centers.

\section{LEGISLATIVE REGULATION OF BANKING OF UMIBILICAL CORD BLOOD STEM CELLS, OTHER HUMAN CELLS AND TISSUES IN UKRAINE}

Ukraine for a long time has been known for significant achievements in cryobiology, advancing the best world centers due to the level of national methodic for cryopreservation of the biological material. It was in Ukraine in 1984 that the first cord blood samples in Europe were preserved. However, because of a number of economic factors cord blood banking in Ukraine launched and was developing a little differently and slowly compared to other European countries [21, 22, 43].

In the developed world in the end of $20^{\text {th }}$ - beginning of $21^{\text {st }}$ century public cord blood banks from state funding appeared, what was mediated by the needs of hematologic clinics for hematopoietic stem cell transplants, high cost and limited availability of rare phenotype bone marrow samples $[15,16,21,22,43]$. Only with time on world medical market the service of personal storage of umbilical cord blood for the family needs appeared and a strong modern culture of biological insurance formed [15-17, 43]. In Ukraine, cord blood banking began from the service of personal cryostorage of stem cells when in 2004 on the base of the Institute of Cell Therapy the first cord blood cryobank was created [21, 22, 43]. Enthusiastic Ukrainian scientists played a significant role in it, trying to introduce in practical health care system methods of cryopreservation of stem cells and tissues they developed, meeting the best world standards.

Actuality of cord blood cryopreservation in Ukraine is mediated by the high oncologic morbidity after the catastrophe on Chernobyl atomic station in 1986, lack of the possibility of unrelated transplants and high culture of parenthood, typical for Slavonia's [43].

Today the activity of banks of the umbilical cord blood, other human tissues and cells is regulated by the following, laws, orders and decrees:

- The Law of Ukraine «On the Transplantation of Organs and Other Anatomical Materials in Humans".

This Act due to the current state of the science and recommendations of the World Health Organization defines the conditions and procedures for applying the method of transplantation as a special treatment, ensures the compliance of human rights and human dignity in Ukraine in the application of transplantation and the implementation of other related activities.

- $\quad$ Order of the Ministry of Health of Ukraine «On Approval of the Procedure of the Collection and Temporary Storage of Umbilical Cord (Placental) Blood».

Regulates the collection and temporary storage of umbilical cord (placental) blood, establishes the forms and procedure of conduction of the accompanying documentation.

- Decree of the Ministry of Health of Ukraine «On Approval of the License Terms of Economic Activities of the Banks of Umbilical Cord Blood and Other Human Tissues and Cells according to the list approved by the Ministry of Health.

Establishes License conditions for the business activity of the banks of the umbilical cord blood, other human tissues and cells according to the list approved by the Ministry of Health [38].

- Licensing conditions on the business activities of the banks of umbilical cord blood and other human tissues and cells according to the list approved by the Ministry of Health.

Define the conditions of business activities of the banks of the umbilical cord blood, other human tissues and cells: material and technical base, requirements to the personnel as well as the list of documents, which are attached to the application for the license. Hence, Law of Ukraine «On licensing of certain types of business activities" (paragraph 16 of the part 1 of the article 7 and paragraph 1 of the part 2 of the article 9) implicates that such type of business activity as "The activity of the banks of umbilical cord blood, other human tissues and cells" should be licensed. All organizations engaged in processing and storage of the umbilical cord blood in Ukraine should comply to mentioned above licensing demands and hold a license on the business activity of the banks of the umbilical cord blood, other human tissues and cells [38].

- Order of the Ministry of Health of Ukraine «On Approval of the Procedure for Conducting Clinical Trials of Tissue and Cell Transplants and Expertise of the Materials of the Clinical Trials".

Establishes the Conditions of the conduction of clinical trials of tissue and cell transplants and expertise of the materials of the clinical trials. [39].

- Resolution of the Cabinet of Ministers of Ukraine «On Measures for the Organization of Health Care and Research Institutions Associated with Transplantation of Organs, Tissues and Cells».

Regulates the use of tissues and cells transplants as a treatment by health and academic institutions, regardless of their subordination solely on the basis of a permission issued according to the results of clinical trials. The order approves clinical trials of tissue and cell transplants and expertise of the materials of clinical trials considering their application in clinical practice. [40].

\section{- The Law of Ukraine «On the Donorship of Blood and its Com-} ponents".

Regulates the use of tissues and cells transplants as a treatment by health and academic institutions, regardless of their subordination solely on the basis of a permission issued according to the results of clinical trials. The order approves clinical trials of tissue and cell transplants and expertise of the materials of clinical trials considering their application in clinical practice. [41]

In 2012, the Ministry of Health of Ukraine officially approved methods of treatment of pancreonecrosis, critical lower limbs ischemia, burns, frostbites and injuries with the use of cell drugs, developed by the Institute of Cell Therapy (Kyiv) and V. K. Husak Institute of the Emergency and Reconstructive Surgery (Donetsk).

The important vectors of the further development of the banking of umbilical cord blood stem cells, other human cells and tissues and regenerative medicine in Ukraine is the creation of the national public cord blood bank and harmonization of the legislation on clinical studies with the use of stem cells. 


\section{REFERENCES}

1. NetCord-FACT International Standards Fifth Edition 70. Available: https://www.factweb.org/forms/store/ProductFormPublic/search?action=1\&Product productNumber $=627$

2. Arjmand B, Emami-Razavi SH, Larijani B, et al. The implementation of tissue banking experiences for setting up a cGMP cell manufacturing facility. Cell Tissue Bank. 2012; 13(4): 587-96.

3. The Rules Governing Medicinal Products in the European Union of EU Guidelines to Good Manufacturing Practice Medicinal Products for Human and Veterinary Use. http://ec.europa.eu/health/files/eudralex/vol-4/pdfs-/2008_02_12_introduction_gmp_en.pdf

4. Bosse R, Singhofer-Wowra M, Rosenthal F, et al. Good manufacturing practice production of human stem cells for somatic cell and gene therapy. Stem Cells. 1997; 15(1): 275-80.

5. FACT-JACIE International Standards for Cellular Therapy Product Collection, Processing, and Administration. Available: www.factwebsite.org/

6. Directive 2004/23/EC of the European Parliament and of the Council of 31 March 2004 on Setting Standards of Quality and Safety for the Donation, Procurement, Testing, Processing, Preservation, Storage and Distribution of Human Tissues and Cells. Available: http://eur-lex.europa.eu/Lex-UriServ/LexUriServ.do?uri=0J:L:2004 :102:0048:0058:en:PDF

7. Leemhuis T, Padley D, Keever-Taylor C, et al. Graft Processing Subcommittee of the Worldwide Network for Blood and Bone Marrow Transplantation (WBMT). Essential requirements for setting up a stem cell processing laboratory. Bone Marrow Transplant. 2014; 49 (8): 1098-105.

8. FDA Guidance for Industry: Minimally Manipulated, Unrelated Allogeneic Placental/Umbilical Cord Blood Intended for Hematopoietic Reconstitution for Specified Indications. Available: http://www.fda.gov/downloads/BiologicsBloodVaccines/GuidanceComplianceRegulatorylnformation/Guidances/Blood/UCM187144.pdf

9. Guidance for Industry and FDA Staff: Investigational New Drug Applications (INDs) for Minimally Manipulated, Unrelated Allogeneic Placental/Umbilical Cord Blood Intended for Hematopoietic Reconstitution for Specified Indications. Available: http://www.fda.gov/BiologicsBloodVaccines/GuidanceComplianceRegulatoryInformati on/Guidances/CellularandGeneTherapy/ucm388218.htm

10. GoodTissuePractices(GTP)\&Reporting.Available:http://www.fda.gov/BiologicsBloodVaccines/SafetyAvailability/ReportaProblem/GoodTissuePracticesGTPReporting/ default.htm

11. AABB Accredited Cord Blood (CB) Facilities. Available: http://www.aabb.org/sa/facilities/celltherapy/Pages/CordBloodAccrFac.aspx

12. http://parentsguidecordblood.org/accreditation.php

13. Burnett D, Blair C, Haeney MR, et al. Clinical pathology accreditation: standards for the medical laboratory. J Clin Pathol. 2002; 55: 729-33.

14. Petrou IG, Grognuz A, Hirt-Burri N, et al. Cell therapies for tendons: old cell choice for modern innovation. Swiss Med Wkly. 2014; 7: 144.

15. Proceedings of the World Cord Blood Congress v \& Innovative Cell Therapies 2015 March 5-8, 2015 - Monaco.

16. Overview of the World congress on cord blood and innovative approaches to the treatment of sickle-cell anemia in Monaco on 24-27 ${ }^{\text {th }}$ october 2013. Cell and Organ Transplantology. 2014; 2(1): 90-4.

17. http://stemcellbank.org.ua/

18. Nasadyuk CM. Cell technologies in reproductology, obstetrics and gynecology. Cell and Organ Transplantology. 2013; 1(1): 56-60.

19. Nasadyuk CM. Stem Cell Therapy In The Treatment Of Inflammatory Bowel Disease. Gastroenterology\&Hepatology: Open Access. 2014; 1(1): 00006.

20. Nasadyuk CM. Cell Therapy in Gastroenterology. Cell and Organ Transplantology. 2015; 3(1): 78-81.

21. Martynenko SI, Makhinya AV, Nasadyuk CM. 11 years of cord blood banking in Ukraine. Cell and Organ Transplantology. 2014; 2(2): 180.

22. Nasadyuk CM. Current status and Perspectives of Cord Blood Cryostorage and Clinical Application in Ukraine. Cellular Transplantation and Tissue Engineering. 2011; 6(1): $98-104$.

23. Nasadyuk CM. Placental stem cells: biological characteristics and approaches to clinical application. Cell and Organ Transplantology. 2014; $2(2)$ : 140-43.

24. https://clinicaltrials.gov

25. http://www.iss.it/

26. Polchow B, Kebbel K, Schmiedeknecht $\mathrm{G}$, et al. Cryopreservation of human vascular umbilical cord cells under good manufacturing practice conditions for future cell banks. J Transl Med. 2012; 10: 98.

27. Matsumoto M. Monica, Dajani Rana, Matthews Kirstin RW. Cord Blood Banking in the Arab World: Current Status and Future Developments. Biol Blood Marrow Transplant. 2015; 21: 1188-94.

28. Operational Guidelines for Ethics Committees That Review Biomedical Research World Health Organization Geneva 2000. Available: http://www.who.int/tdr/ publications/training-guideline-publications/operational-guidelines-ethics-biomedical-research/en/

29. International Declaration on Human Genetic Data: UNESCO, 1997. Available: http://portal.unesco.org/en/ev.php-url_id=17720\&url_do=do_topic\&url_section=201. html

30. Additional protocol to the convention on human rights and biomedicine concerning biomedical research. 2004. Available: http://www.ub.edu/recerca/Bioetica/doc/ Protocol_Biomedical_research.pdf

31. Convention for the protection of Human Rights and dignity of the human being with regard to the application of biology and medicine: Convention on Human Rights and Biomedicine. Available: http://www.eubios.info/EJ123/ej123d.htm

32. Oviedo - Convention for the protection of Human Rights and dignity of the human being with regard to the application of biology and medicine: Convention on Human Rights and Biomedicine. Available: https://rm.coe.int/CoERMPublicCommonSearchServices/DisplayDCTMContent?documentld=090000168007cf98

33. Additional Protocol to the Convention on Human Rights and Biomedicine, concerning Genetic Testing for Health Purposes. Available: https://rm.coe.int/ CoERMPublicCommonSearchServices/DisplayDCTMContent?documentld=0900001680084824

34. Directive 2001/20/EC of the European Parliament and of the Council of 4 April 2001 on the approximation of the laws, regulations and administrative provisions of the Member States relating to the implementation of good clinical practice in the conduct of clinical trials on medicinal products for human use. Available: http://ec.europa. eu/health/files/eudralex/vol-1/dir_2001_20/dir_2001_20_en.pdf

35. Directive 95/46/EC of the European Parliament and of the Council of 24 October 1995 on the protection of individuals with regard to the processing of personal data and on the free movement of such data. Available: http://ec.europa.eu/justice/policies/privacy/docs/95-46-ce/dir1995-46_part1_en.pdf

36. EU Directive 2004/23/EC: towards standards of quality and safety for human tissues and cells in Europe. Available: http://eur-lex.europa.eu/legal-content/EN/ TXT/?uri=celex:32004L0023

37. Directive 2004/23/EC of the European Parliament and of the Council of 31 March 2004 on setting standards of quality and safety for the donation, procurement, testing, processing, preservation, storage and distribution of human tissues and cells. Available: http://eur-lex.europa.eu/Lex-UriServ/LexUriServ.do?uri=0J:L:2004:102:0048: 0058:en:PDF 
38. Litsenziyni umovi provadzhennya gospodars'koï diyal'nosti bankiv pupovinnoï krovi, inshikh tkanin i klitin lyudini zgidno z perelikom, zatverdzhenim Ministerstvom okhoroni zdorov'ya, zatverdzheni postanovoyu Kabinetu Ministriv Ukraïni vid 02.03 .2016 r. N 286 [Licensing conditions for the business activities of banks of umbilical cord blood and other tissues and cells in accordance with the list approved by the Ministry of Health, approved by the Cabinet of Ministers of Ukraine 02.03.2016, \# 286] Available: http://zakon0.rada.gov.ua/laws/show/286-2016-\%D0\%BF

39. Pro zatverdzhennya Poryadku provedennya klinichnikh viprobuvan' tkaninnikh i klitinnikh transplantativ ta ekspertizi materialiv klinichnikh viprobuvan' y unesennya zmin do Poryadku provedennya klinichnikh viprobuvan' likars'kikh zasobiv ta ekspertizi materialiv klinichnikh viprobuvan', zatverdzhenogo nakazom Ministerstva okhoroni zdorov'ya Ukraïni vid 13.02.2006 N 66, zareestrovanogo v Ministerstvi yustitsiï Ukraïni 10.03.2006 za N 252/12126 Nakaz Ministerstva okhoroni zdorov'ya Ukraïni vid 10 zhovtnya 2007 roku N 630. [On approval of clinical trials of tissue and cell transplants and expertise of clinical trials and amending the procedure for clinical trials and expertise of clinical trials approved by the Ministry of Health of Ukraine, 13.02.2006 \# 66, registered in the Ministry of Justice Ukraine 10.03.2006 \# 252/12126 Order of the Ministry of health of Ukraine, October 10, 2007 \# 630]. Available: http://zakon5.rada.gov.ua/laws/show/z1206-07

40. Postanova vid 5 veresnya 2007 r. N 1100 Kiïv Pro zakhodi shchodo organizatsiï diyal'nosti zakladiv okhoroni zdorov'ya ta naukovikh ustanov, pov'yazanoï z transplantatsieyu organiv, tkanin i klitin. [Decree of September 5, 2007, \# 1100, Kyiv. On Measures for the Organization of Health Care and Research Institutions Associated with Transplantation of Organs, Tissues and Cells]. Available: http://zakon4.rada.gov.ua/laws/show/1100-2007-\%D0\%BF

41. Zakon Ukraïni Pro donorstvo krovi ta ï komponentiv vid 23.06.95 [Law of Ukraine «On Donation of Blood and Blood Components»]. Available: http://zakon4.rada.gov. ua/laws/show/239/95-\%D0\%B2\%D1\%80

42. www.cordblood.com

43. Nasadyuk CM, Makhinya AV, Zak SO, et al. Current status and perspectives of cryostorage and clinical application of the umbilical cord blood in Ukraine and in the world. Cell and Organ Transplantology. 2015; 3(2): 208-213.

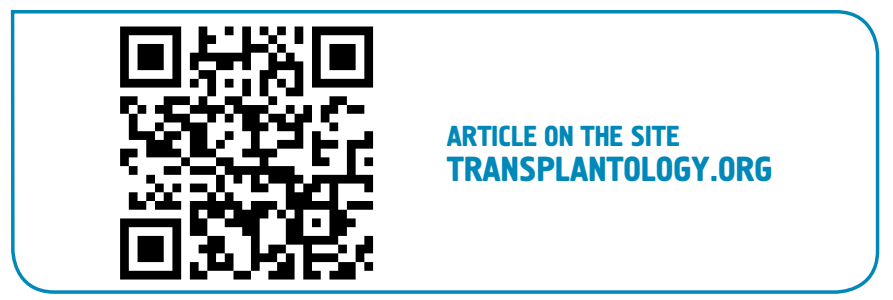

The authors indicate no potential conflicts of interest.

Received: January 12, 2016

Accepted: May 16, 2016 